Література

1. Бутинець Ф. Ф. Інформаційні системи і технології в обліку / Ф. Ф. Бутинець, Т. В. Давидюк, інші. - Ж: Рута, 2007. - 468 с.

2. Инвестиционный анализ (учебное пособие) Асаул А.Н., Биба В.В., Буняк В.Л. /Международный журнал экспериментального образования. №8, 2015.- С. 277-278.

3. Голубнича Г.П. Особливості організації обліку та облікової політики на малих підприємствах підприємства // Крымский экономический вестник.№1(14).- 2015.- С. 75-78.

4. Голубнича Г. П. Категории «знание бизнеса» и «бизнес-модель» предприятия: содержание и практическое значение//Научный взгляд в будущее. 2016. - Выпуск 4. Том 6. Экономика. - С. 78-82.

5. Golubnicha G.P. Research a component during preparation of experts under the account, the economic analysis and audit at universities//Вісник КНУ імені Тараса Шевченка. Економіка.-№101.-2008.-С.21-25.

6. Голубничая Г.П., Буняк В.Л. Переход финансовой отчётности организаций на МСФО и инвестиционные процессы // Саморазвитие, самоуправление и трансформационные изменения в инвестиционностроительной сфере.-СПб, 2013. Том. 1. - С. 293-304.

7. Терещенко Л.О. Інформаційни системи і технології в обліку /Л.О. Терещенко, I.I. Матієнко-Зубенко. - К.: КНЕУ, 2013. - 157 с.

8. Усач Б.Ф. Удосконалення організації обліку, аналізу i аудиту фінансового стану суб'єктів господарювання: монографія/Б. Ф. Усача. - К.: УБС НБУ, 2011. - $352 \mathrm{c}$.

Стаття відправлена: 08.06.2017. (C) Хахутаішвілі К. Н.

\title{
ЦИТ: иа217-084
}

DOI: 10.21893/2415-7538.2017-06-4-084

УДК 657.1

Федченко Т.B.

\section{ОРГАНИЗАЦИЯ ПРОЦЕССА ПОДГОТОВКИ ФИНАНСОВОЙ ОТЧЕТНОСТИ ПРЕДПРИЯТИЯ}

ГО ВПО «Донеикий национальный университет экономики и торговли имени Михаила Туган-Барановского», Донеик, Щорса 31, 83050

Fedchenko T.V. ORGANIZATION OF THE PROCESS OF PREPARING THE FINANCIAL REPORTING OF THE ENTERPRISE

SO HPE «Donetsk National University of Economics and Trade named after Mykhayilo Tugan-Baranovsky»,Donetsk, Shchors Street 31, 83050

Аннотация. В работе рассматривается сущуность терминов «организация» и «организация бухгалтерского учета», предлагается авторское определение «организация процесса подготовки финансовой отчетности 
предприятия», раскрываются виды прочессов организачии бухгалтерского учета, описываются принципь процесса организации подготовки финансовой отчетности предприятия.

Ключевые слова: организачия, прочесс, бухгалтерский учет, регламенты, финансовая отчетность, приничипь.

Abstract. The author considers the essence of the terms "organization" and "organization of accounting", proposes the definition of "organization of the process of preparing the financial reporting of the enterprise", discloses the types of accounting, describes the principles of the organization of preparing of the financial reporting of the enterprise.

Key words: organization, process, accounting, regulations, financial reporting, principles.

Вступление. Учетный процесс является достаточно сложным в условиях изменчивости законодательства и экономической ситуации, поэтому вопросы его организации занимают особое место при изучении теории бухгалтерского учета. Актуальность исследования базируется на мнении, что, используя принципы распределения обязанностей и специализации, возникает острая необходимость рассмотрения вопросов организации процесса подготовки финансовой отчетности предприятия, так как качество и достоверность информации напрямую зависят от компетенции бухгалтеров и руководства предприятия, подходов к управлению и организационных особенностей хозяйствующего субъекта.

Исследованность проблемы. Вопросы организации затронуты в законодательстве [1], в том числе бухгалтерского учета и подготовки финансовой отчетности, занимались многие ученые: И.А. Власова, Э.С. Гейер, В. Грибов, В. Грузинов, Б.3. Мильнер, О.А. Наумчук, С.Н. Петренко, В.С.Рапопорт, Е.Д. Чацкис, И. В. Сименко, Л. А. Сухарева и другие [2-9].

Основной текст. Согласно Закона Украины «О бухгалтерском учете и финансовой отчетности в Украине» [1] вопросы организации бухгалтерского учета на предприятии относятся к компетенции его собственника (собственников) или уполномоченного органа (должностного лица), который и несет ответственность за его эффективность.

Организация бухгалтерского учета также по положениям законодательства предполагает, что предприятию необходимо самостоятельно: определить форму организации бухгалтерского учета, учетную политику; выбрать форму бухгалтерского учета как определенную систему регистров, способа регистрации и обобщения информации в них; утвердить правила документооборота и технологию обработки учетной информации; разрабатывает систему и формы внутрихозяйственного (управленческого) учета, отчетности и контроля хозяйственных операций; может выделять на отдельный баланс филиалы, представительства, отделения и другие обособленные подразделения; определяет целесообразность применения международных стандартов [1].

Термин «организация» может использоваться как функция управления, а также когда «организацию» рассматривают как предприятие, то есть реально 
существующий субъект. Между тем все эти аспекты понятия «организация» не следует рассматривать как нечто единое и строго регламентированое. Смысловое понятие «организация» следует воспринимать как порядок, последовательность или систему совокупности предметов (понятий) [3].

Обратившись к дефиниции «организация» и «организация бухгалтерского учета», выясняется, что она имеет различные оттенки значения (табл. 1).

Таблица 1

Сущность понятий «организация» и «организация бухгалтерского учета»

\begin{tabular}{|c|c|}
\hline Понятия & ность понятия \\
\hline $\begin{array}{l}\text { Организация как } \\
\text { объект }\end{array}$ & $\begin{array}{l}\text { является целостным комплексом взаимосвязанных элементов и } \\
\text { взаимодействий с внешним окружением. Для нее характерна } \\
\text { целенаправленность функционирования и развития [4]; }\end{array}$ \\
\hline $\begin{array}{l}\text { Организация как } \\
\text { явление }\end{array}$ & $\begin{array}{l}\text { является объединением элементов для реализации программы или } \\
\text { цели, действует на основе определенных правил и процедур }[5, \\
\text { с.10]; }\end{array}$ \\
\hline \multirow[t]{2}{*}{$\begin{array}{l}\text { Организация как } \\
\text { процесс }\end{array}$} & $\begin{array}{l}\text { 1) это проявление общественной деятельности, основанной на } \\
\text { разделении труда; }\end{array}$ \\
\hline & $\begin{array}{l}\text { 2) это совокупность действий, ведущих к созданию и } \\
\text { совершенствованию взаимосвязей между частями целого [3, с. } \\
\text { 136]; }\end{array}$ \\
\hline $\begin{array}{l}\text { Организация как } \\
\text { система }\end{array}$ & $\begin{array}{l}\text { работающая для достижения поставленной цели в определенных } \\
\text { условиях, в рамках установленных сроков, причем обязательным } \\
\text { становится использование специально разработанных методов, } \\
\text { направленных на оптимизацию расходования ресурсов и } \\
\text { сокращение всевозможных затрат [6]; }\end{array}$ \\
\hline $\begin{array}{l}\text { Если рассматривать } \\
\text { организацию } \\
\text { применительно к } \\
\text { производственным } \\
\text { отношениям } \\
\end{array}$ & $\begin{array}{l}\text { система мер, направленных на рациональное сочетание всех } \\
\text { элементов производства (рабочие силы, предметы труда, орудия } \\
\text { труда) во времени и пространстве для достижения конкретного } \\
\text { единого результата [6]; }\end{array}$ \\
\hline \multirow[t]{2}{*}{$\begin{array}{l}\text { Организация } \\
\text { бухгалтерского учета }\end{array}$} & $\begin{array}{l}\text { 1) это система условий и элементов построения учетного процесса } \\
\text { с целью получения достоверной и своевременной информации о } \\
\text { хозяйственной деятельности предприятия и осуществления } \\
\text { контроля за рациональным использованием производственных } \\
\text { ресурсов и наиболее выгодной продажей готовой продукции. В } \\
\text { самом общем виде это упорядочение, приведение чего-либо в } \\
\text { систему. Организация предполагает порядок, сохранение и } \\
\text { поддержание состояния определенной упорядоченности } \\
\begin{array}{l}\text { элементов системы в целом, поддержание качества ее } \\
\text { определенности [7]; }\end{array}\end{array}$ \\
\hline & $\begin{array}{l}\text { 2) рассматривается как совокупность методов, мероприятий, } \\
\text { обеспечивающих функционирование учета и его дальнейшее } \\
\text { развитие, как целенаправленную деятельность по упорядочению и } \\
\text { совершенствованию системы бухгалтерского учета [2]. }\end{array}$ \\
\hline
\end{tabular}

Так как к процессным компонентам самого понятия организации относят такие действия, как «основать», «учредить», «объединить», «упорядочить», «подготовить». Исходя из данных компонентов, можно вывести следующее определение: организация процесса подготовки финансовой отчетности предприятия - установление последовательности целевого соподчиненного и 
согласованного в пространстве и времени взаимодействия субъектов бухгалтерского учета с целью накопления подтвержденной документально информации в регистрах учета и формирования показателей в финансовой отчетности на основе бухгалтерских стандартов и национального законодательства, а также принципов полноты и достоверности (разработка автора).

Однако, организация не состоит из одного конечного процесса, напротив, процессов может быть множество, которое в итоге и составит полноценный, комплексный процесс организации [6]. Поэтому все процессы в бухгалтерии, подлежащие организации, объединены в определенные виды (предложено на основе [6]):

1. Организация трудовых процессов - выработка и установление рациональных связей между субъектом (работник бухгалтерии), его орудием труда (знания, навыки, техника и технология) и предметом труда (показатели финансовой отчетности). Предполагает разработку регламентов по организации труда (правил трудового распорядка) и бухгалтерского учета (учетная политика); методических указаний и инструкций по регистрации хозяйственных операций и составлению финансовой отчетности.

2. Организация информационных потоков - создание и поддержание коммуникационных связей, технологических связей между различными элементами, подсистемами учетной структуры (администрирование информационных систем на предприятии, интеграция программного обеспечения бухгалтерского учета в программу системы управления, разработка графиков документооборота, рабочего плана счетов, альбома форм первичных документов, определение подхода к архивному делопроизводству).

3. Организация управления - установление и обслуживание структурнофункциональных связей между элементами управленческого аппарата и учетной структурой: разработка «Положения о бухгалтерии», должностных инструкций Главного бухгалтера и рядовых бухгалтеров.

Процессу организации подготовки финансовой отчетности предприятия должны быть присущи следующие принципы (составлено на основе [2, 3-6, 8, 9]), систематизированные в табл. 2.

Соблюдение принципов организации процесса подготовки финансовой отчетности предприятия имеет большое практическое значение, так как способствует рациональному использованию потенциала работников бухгалтерии и повышению эффективности учетной работы, что в свою очередь обеспечивает полноту отражения всех хозяйственных операций через систему бухгалтерских счетов и регистров в финансовой отчетности.

Заключение и выводы. В научной статье были рассмотрены сущность терминов «организация» и «организация бухгалтерского учета»; раскрыты виды процессов организации бухгалтерского учета. Автором были получены следующие теоретические положения: предложено авторское определение «организация процесса подготовки финансовой отчетности предприятия», описаны принципы процесса организации подготовки финансовой отчетности предприятия. 


\section{Принципы организации подготовки финансовой отчетности}

\begin{tabular}{|c|c|}
\hline Принципы & Экономическая характеристика \\
\hline Комплексность & $\begin{array}{l}\text { сложность и полнота охвата объектов учета - оперирует величинами, } \\
\text { определяющими степень дифференциации в рамках каждой организации. } \\
\text { Включает в себя уровень специализации (разделения труда по участкам } \\
\text { учета), количество уровней в иерархии и степень территориального } \\
\text { распределения подразделений (филиалы, представительства, посольства) } \\
\text { - формализация организационной структуры предприятия и разработка } \\
\text { положений о структурных подразделениях. }\end{array}$ \\
\hline $\begin{array}{l}\text { Регла } \\
\text { дейст }\end{array}$ & $\begin{array}{l}\text { заранее разработанные и установленные для организации правила, } \\
\text { процедуры, определяющие поведение работников (составление } \\
\text { должностных инструкций, правил трудового распорядка). }\end{array}$ \\
\hline $\begin{array}{l}\text { Соотношение } \\
\text { централизации и } \\
\text { децентрализации } \\
\end{array}$ & $\begin{array}{l}\text { данный принцип определяется уровнем, на котором вырабатываются и } \\
\text { принимаются управленческие решения (иерархия в организаци, } \\
\text { сложность организационной структуры). }\end{array}$ \\
\hline $\begin{array}{l}\text { Техническая } \\
\text { оснащенность }\end{array}$ & $\begin{array}{l}\text { наличие современного программного обеспечения, } \\
\text { коммуникаций (телефония, Интернет, внутренняя сеть); }\end{array}$ \\
\hline Компетентность & $\begin{array}{l}\text { работники бухгалтерии должны иметь профильное образование, обладать } \\
\text { знаниями по бухгалтерскому учету и контролю, коммуникабельностью, } \\
\text { владеть навыками работы с программным обеспечением, хорошо } \\
\text { ориентироваться в законодательстве государства, стремиться к } \\
\text { повышению квалификации и самореализации. }\end{array}$ \\
\hline Параллельность & $\begin{array}{l}\text { процедуры внутреннего контроля должны быть параллельны с } \\
\text { оформлением первичных документов по хозяйственным операциям, } \\
\text { накоплением информации в регистрах учета и составлением финансовой } \\
\text { отчетности. }\end{array}$ \\
\hline Дост & $\begin{array}{l}\text { каждый показатель в финансовой отчетности должен подтверждаться } \\
\text { данными из регистров бухгалтерского учета и первичными документами } \\
\text { на совершенные хозяйственные операции, которые несут изменения в } \\
\text { активах, собственном капитале и обязательствах, формируют финансовый } \\
\text { результат предприятия. }\end{array}$ \\
\hline Гочность & $\begin{array}{l}\text { предполагает такую организацию процесса подготовки финансовой } \\
\text { отчетности предприятия, при которой обеспечивается в кратчайшие сроки } \\
\text { сбор информации для формирования показателей отчетности, кратчайший } \\
\text { путь движения документов от составителя до пользователя информации } \\
\text { об имущественном состоянии и источниках финансирования. Соблюдение } \\
\text { принципа прямоточности приведет к упорядочению документаци, } \\
\text { сокращению трудозатрат работников бухгалтерии, уменьшению затрат на } \\
\text { тиражирование документов, предупредит дублирование учетных работ. }\end{array}$ \\
\hline $\begin{array}{l}\text { Принцип } \\
\text { единоначалия и } \\
\text { коллегиальности }\end{array}$ & $\begin{array}{l}\text { руководитель, придерживающийся единоначалия, решает ряд } \\
\text { возникающих вопросов строго самостоятельно, при этом качественный } \\
\text { уровень решения зависит от компетенции руководителя. Антиподом } \\
\text { единоначалия выступает коллегиальность - выработка коллективного } \\
\text { решения, основанного на мнении руководителей различных уровней, а } \\
\text { также на мнении привлеченных специалистов. }\end{array}$ \\
\hline венность & $\begin{array}{l}\text { выполнение должностных обязанностей должно сопровождаться } \\
\text { способностью действовать в рамках этических норм на благо } \\
\text { управленческой системы предприятия, стремлением оценить последствия } \\
\text { своих действий и готовностью нести персональное наказание, в случае не } \\
\text { соблюдения установленных норм и правил. }\end{array}$ \\
\hline
\end{tabular}


Литература:

1. Про бухгалтерський облік та фінансову звітність в Україні [Електронний ресурс]. Закон ВР України від 16.07.1999 № 996-XIV. - Режим доступу: https://buhgalter.com.ua/zakonodavstvo/buhgalterskiy-oblik/zakon-ukrayini-probuhgalterskiy-oblik-ta-finansovu-zvitnist-v-ukrayini/

2. Організація бухгалтерського обліку: Практикум для студ. ден. та заоч. форм навчання спец. «Облік та аудит» / М-во освіти і науки України, Донец. нац. ун-т економіки і торгівлі ім. М. Туган-Барановського, ін-т обліку і фінансів, каф. бух. обліку; Ю.Д. Чацкіс, Е.С. Гейєр, О.А. Наумчук, І.О. Власова. - Донецьк: ДонНУЕТ, 2010. - 125 с.

3. Петренко С.М. Внутрішній контроль: проблеми інформаційного, організаційного та методологічного розвитку : [монографія] / С.М.Петренко; Мво освіти і науки, молоді та спорту України, Донец. нац. ун. економіки і торгівлі ім. Михайла Туган-Барановського. - Донецк: ДонНУЕТ, 2013. - 509 с.

4. Мильнер Б.З. Системный подход к организации управления / Б.З. Мильнер, Л.И. Ревенко, В.С. Рапопорт. - М.: Экономика, 1983. - 224 с.

5. Минцберг Г. Структура в кулаке: создание эффективной организации / Минцберг Г.; пер. с англ.; под ред. Ю.Н. Каптуревского. - СПб.: Питер, 2002. $512 \mathrm{c}$.

6. Организация, как объект управления [Электронный ресурс] // Теория организации. - Manageconom.Ru. - Режим доступа: http://manageconom.ru/orgtheory/organization-as-control-object.htm

7. Организация бухгалтерского учета [Электронный ресурс] // Словарь бизнес-терминов. Академик.ру. 2001 . - Режим доступа: http://dic.academic.ru/dic.nsf/business/20026/ОРГАНИЗАЦИЯ БУХГАЛТЕРСКО ГО УЧETA

8. Сименко И. В. Социальная отчетность как объект диагностирования экосоциоэкономических отношений корпораций [Электронный ресурс] / И. В. Сименко, Л. А. Сухарева, Т. В. Федченко. // Торговля и рынок : науч. журн. 2016-. 2016. № 1. - С. 204-210 : табл.

9. Грибов В. Принципы организации производственного процесса [Электронный ресурс] / В. Грибов, В. Грузинов. - Центр Креативных Технологий. - Режим доступа: https://www.inventech.ru/lib/predpr/predpr0019/

Статья отправлена: 10.06.2017 г. (C) Федченко Т.В.

\section{ЦИТ: иа217-015}

DOI: 10.21893/2415-7538.2017-06-4-015

УДК 004.2

Ошлакова И.С.

ОРГАНИЗАЦИОННАЯ КУЛЬТУРА КАК СРЕДСТВО ДОСТИЖЕНИЯ БИЗНЕС ЦЕЛЕЙ НА ПРЕДПРИЯТИЯХ СЕРВИСНОГО ТИПА

Владивостокский Государственный Университет Экономики и Сервиса, Владивосток, ул.Гоголя 41, 690014 